\title{
Realistisch revolveren. Het revolverend fonds met een Europese touchlnauguratie
}

Citation for published version (APA):

van den Brink, J. E. (2018). Realistisch revolveren. Het revolverend fonds met een Europese

touchInauguratie: Rede uitgesproken bij de aanvaarding van het ambt van hoogleraar 'Europees en Nationaal Bestuursrecht' aan de Faculteit der Rechtsgeleerdheid van de Universiteit Maastricht. Maastricht University. https://doi.org/10.26481/spe.20180608jb

Document status and date:

Published: 08/06/2018

DOI:

10.26481/spe.20180608jb

Document Version:

Publisher's PDF, also known as Version of record

\section{Please check the document version of this publication:}

- A submitted manuscript is the version of the article upon submission and before peer-review. There can be important differences between the submitted version and the official published version of record.

People interested in the research are advised to contact the author for the final version of the publication, or visit the DOI to the publisher's website.

- The final author version and the galley proof are versions of the publication after peer review.

- The final published version features the final layout of the paper including the volume, issue and page numbers.

Link to publication

\footnotetext{
General rights rights.

- You may freely distribute the URL identifying the publication in the public portal. please follow below link for the End User Agreement:

www.umlib.nl/taverne-license

Take down policy

If you believe that this document breaches copyright please contact us at:

repository@maastrichtuniversity.nl

providing details and we will investigate your claim.
}

Copyright and moral rights for the publications made accessible in the public portal are retained by the authors and/or other copyright owners and it is a condition of accessing publications that users recognise and abide by the legal requirements associated with these

- Users may download and print one copy of any publication from the public portal for the purpose of private study or research.

- You may not further distribute the material or use it for any profit-making activity or commercial gain

If the publication is distributed under the terms of Article $25 \mathrm{fa}$ of the Dutch Copyright Act, indicated by the "Taverne" license above, 
prof. mr. J.E. (Jacobine) van den Brink

Faculteit der Rechtsgeleerdheid

\section{Realistisch revolveren. Het revolverend fonds met een Europese touch}




\section{Realistisch revolveren. Het revolverend fonds met een Europese touch}

Oratie d.d. 8 juni 2018, uitgesproken door prof. mr. J.E. (Jacobine) van den Brink, hoogleraar Europees en nationaal bestuursrecht, Universiteit Maastricht

Mevrouw de rector magnificus, geachte decaan, beste collega's, familie en vrienden,

De financiële relatie tussen de overheid en burger boeit mij al bijna 15 jaar mateloos. Het valt mij op dat de subsidie de laatste jaren aan populariteit inboet. Bij subsidiëren wordt niet langer gedacht aan het in positieve zin ondersteunen van maatschappelijke projecten of instellingen, maar aan het dumpen van overheidsgeld in een bodemloze subsidieput. Termen als "subsidieslurper", "subsidieinfuus", en niet te vergeten "subsidieverslaving" komen we niet alleen op "Geen Stijl", maar ook in kwaliteitskranten tegen. Tel daarbij op het feit dat de effecten van subsidiëring nauwelijks worden gemeten, laat staan aangetoond, en het mag geen verbazing wekken dat de overheid zich steeds meer gedraagt als een "subsidievermijder".

Maar, dit betekent niet dat de overheid opeens veel minder geld is gaan uitgeven aan het stimuleren van allerlei wenselijk geachte activiteiten. Integendeel. Publiek geld wordt nog steeds enthousiast uitgegeven, alleen onder andere benamingen, zoals: publieke prijsvragen, matchfunding, sponsoring, social impact bonds en bewonersbudgetten.

De zogenoemde subsidie nieuwe stijl. Een fenomeen dat snel om zich heen grijpt, waarmee grote sommen geld zijn gemoeid, maar waarvan de juridische randvoorwaarden vaak onduidelijk zijn.

In deze oratie neem ik u mee naar de wondere wereld van een van die nieuwe soorten subsidies. Het revolverend fonds dat is gevuld met publiek geld dat niet wordt uitgegeven maar geïnvesteerd. Subsidie in een hip jasje. Alhoewel hip?

We moeten niet overdrijven: het oudste revolverend fonds van de Rijksoverheid - het Nederlands Restauratiefonds - bestaat al ruim 30 jaar. Wat wel nieuw is, is de omvang van het verschijnsel: een paar uurtjes googelen levert het beeld op dat nieuwe revolverende fondsen anno 2018 als paddenstoelen uit de grond schieten.

Revolverende fondsen vind je terug op allerlei beleidsterreinen, zoals innovatie, energie en cultuur. Ze worden doorgaans als oplossing gezien voor moeizame en trage financiering van maatschappelijk relevante projecten, omdat onvoldoende risicokapitaal aanwezig zou zijn in de private kapitaalmarkt.

De nieuwste loot aan de stam heet Invest-NL. Deze naamloze vennootschap - voor $100 \%$ eigendom van de Staat - bestaat onder meer uit een revolverend fonds van 2,5 miljard euro. Vanaf 2019 moet dit fonds investeren in ondernemingen op het gebied van energie, verduurzaming, voedsel en innovatie.

Er gaat inmiddels heel veel publiek geld om in revolverende fondsen. Het is niet gemakkelijk om het precieze bedrag uit de beschikbare cijfers halen. Maar dat het om miljarden gaat, staat vast! 
Al dat publieke geld rechtvaardigt de vraag hoe deze fondsen zijn gereguleerd. Al snel zal blijken dat die regulering niet veel voorstelt. Dat roept de vraag op of dat wenselijk is, en zo nee, hoe die situatie kan worden verbeterd. De volgende vragen komen daarom in deze oratie aan de orde:

1. Wat is een revolverend fonds?

2. Wat zijn de voordelen van een revolverend fonds ten opzichte van de traditionele subsidie?

3. Worden die beloofde voordelen van het revolverend fonds waargemaakt?

4. Wat zijn de meest dringende juridische problemen met deze revolverende fondsen?

5. Welke oplossingen zijn daarvoor denkbaar? En tot slot

6. Welke lessen zouden wij kunnen leren uit het EU-recht, waar men inmiddels uitgebreide regelgeving voor het revolverend fonds heeft opgesteld?

\section{Wat is een revolverend fonds?}

Wat is dat nu zo'n revolverend fonds?

Kort gezegd gaat het om:

- een fonds dat wordt opgericht door een bestuursorgaan,

- dat is gevuld met publiek geld - het geld van de belastingbetaler dus -,

- vanwaaruit financiering aan derden - meestal ondernemingen - wordt verstrekt,

- die na verloop van tijd weer terugvloeit naar het fonds.

Wat zijn de belangrijkste kenmerken van revolverende fondsen?

In de eerste plaats zijn zij doorgaans gericht op het behalen van een optimale combinatie van maatschappelijk en financieel rendement. Revolverende fondsen ondersteunen maatschappelijke projecten: door de overheid in het algemeen belang wenselijk geachte activiteiten van of met particulieren. Zo creëren zij maatschappelijk rendement: de resultaten zijn goed voor ons allemaal ().

Het fonds UNIIQ investeert bijvoorbeeld in een nieuw soort tafel waarop vroeggeboren baby's in de eerste kritische minuten kunnen worden behandeld, zonder de navelstreng door te knippen. Wie wordt daarvan nu niet enthousiast? Maar omdat het ook de bedoeling is dat het geld terugkeert in het fonds, moeten dergelijke projecten in potentie ook financieel rendement kunnen behalen. $\mathrm{Er}$ moet dus winst worden gemaakt.

Een tweede kenmerk is dat revolverende fondsen op afstand worden geplaatst van de overheid waarvan het publieke geld afkomstig is. Het idee leeft dat overheden en ambtenaren geen verstand hebben van financieren en dat de politiek zo min mogelijk invloed moet hebben op langdurige investeringen. De overheid richt daarom vaak een privaatrechtelijke rechtspersoon op en wordt daarvan aandeelhouder of verstrekt daaraan een subsidie of lening. Deze privaatrechtelijke rechtspersoon wordt vervolgens beheerd door een via een aanbestedingsprocedure geselecteerde fondsmanager. Er zijn bedrijven die in fondsmanagement zijn gespecialiseerd. In een 
investeringsreglement staat onder welke voorwaarden deze fondsmanager met publiek geld mag financieren.

Schematisch ziet de structuur rondom een revolverend fonds er dus ongeveer zo uit:

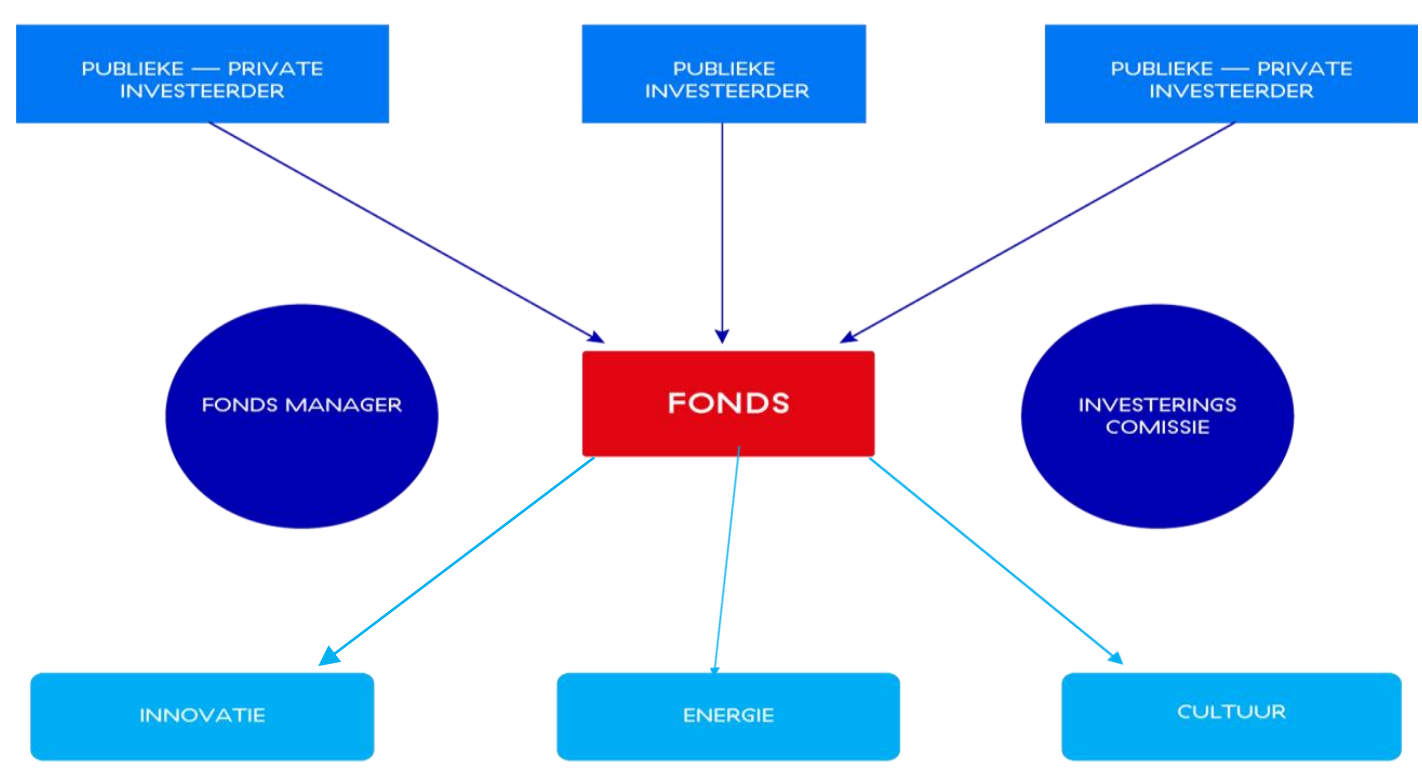

Een derde en misschien wel het belangrijkste kenmerk is dat het geld in revolverende fondsen 'ronddraait'. Het revolveert. Als het goed is, keert het geld dus weer terug in het fonds. Soms wordt zelfs winst behaald. De overheid subsidieert immers niet, maar investeert in de vorm van participaties, leningen en garanties. Hieruit verkregen opbrengsten uit verkoop van de aandelen, dividend, aflossingen, rente en premies vloeien terug in het fonds. Met als resultaat dat de middelen opnieuw kunnen worden ingezet.

\section{Wat zijn nu de voordelen van revolverend financieren ten opzichte van traditioneel subsidiëren?}

Om deze vraag te kunnen beantwoorden, is het van belang vast te stellen dat het imago van de subsidie de afgelopen jaren is verslechterd. Een veelgehoorde klacht is de inflexibiliteit en het tijdrovende karakter van subsidieprocedures. Besluitvormingsprocedures zijn formeel en bezwaaren beroepsmogelijkheden voor ontevreden aanvragers haast oneindig. Hierdoor blijven kansen onbenut; private partners willen niet wachten op een trage overheid. Ook veelgehoord is de onwenselijke invloed van 'de politiek' op besluitvormingsprocedures. Politici handelen op basis van politieke motieven, waardoor niet de meest veelbelovende projecten worden gefinancierd. Bovendien wijzigt de politieke visie op wat wenselijk is voortdurend, terwijl veelbelovende projecten vaak een lange looptijd kennen. Daarnaast past de beschikking als eenzijdig overheidsinstrument 
niet bij de huidige visie op publiek-private samenwerking. De overheid is niet langer een eenzijdig besluitnemer, maar een gelijkwaardig partner of facilitator. Ten slotte maken subsidieregelingen ontvangers niet creatief, maar alleen maar lui.

Deze negatieve reclame heeft ertoe geleid dat in een rap tempo allerlei nieuwe financieringsinstrumenten zijn ontstaan, waaronder het revolverend fonds. Wat zijn hiervan de voordelen boven de subsidie?

In de eerste plaats wordt het geïnvesteerde geld als gezegd terugontvangen door het fonds. In de tweede plaats, versterkt het investeren door de overheid het vertrouwen van marktpartijen. Dit vergroot de kans dat ook private kapitaalverschaffers willen investeren, in een specifiek project of in het revolverend fonds zelf. Meer geld dus voor al die mooie doelstellingen. De andere twee voordelen vormen het spiegelbeeld van de zojuist genoemde nadelen van de subsidie. De begunstigde zou beter zijn best doen omdat een lening nou eenmaal moet worden terugbetaald. En een overheid op afstand betekent een efficiëntere besteding van overheidsgeld.

Deze vermeende voordelen hebben ertoe geleid dat bijna elke zichzelf serieus nemende overheid een revolverend fonds heeft opgericht of daarin deelneemt: provincies, gemeenten, waterschappen en ook het Rijk. Overheden die geen eigen geld hebben, zetten nota bene fondsen op met geleend geld. Hoewel dit wettelijk is toegestaan, levert dit wel een extra financieel risico op. Ook als het revolverend fonds leegloopt door onverstandige investeringen, moet de voor het fonds aangegane lening immers worden terugbetaald.

\section{Worden die beloofde voordelen van het revolverend fonds waargemaakt?}

Publiek geld dat ronddraait en steeds opnieuw kan worden ingezet, een modern kruikje van Sarfath: het klinkt natuurlijk allemaal prachtig, maar worden de beloften van de revolverend fondsen nu ook echt waargemaakt? Gaat het hier om de kip met gouden eieren?

Helaas is geen overkoepelend cijfermatig onderzoek beschikbaar, dat deze vraag beantwoordt. De Algemene Rekenkamer is momenteel bezig met een onderzoek naar de revolverende fondsen van het Rijk, maar daarvan zijn de resultaten nog niet bekend. Uit de wel beschikbare onderzoeken en uit door mij gehouden interviews met betrokkenen komt het volgende beeld naar voren.

In de eerste plaats zijn de meeste revolverende fondsen uitsluitend gevuld met publiek geld. Private financiers investeren niet op fondsniveau, maar alleen in concrete projecten. In dat geval kunnen zij zelfstandig en per concreet project een afweging maken om mee te doen. Bij het investeren op fondsniveau is dat niet mogelijk.

Ten tweede raken sommige revolverende fondsen maar lastig hun geld kwijt. Een voorbeeld is het Brabantse Breedbandfonds. Het bedrijf dat in Noord-Brabant breedband zou gaan aanleggen en van dit Brabantse fonds een lening van 35 miljoen euro had ontvangen, zag daarvan op het allerlaatste moment af omdat de benodigde financiering toch via de markt kon worden verkregen. Het Friese Breedbandfonds is inmiddels helemaal opgeheven omdat het niemand lukte om aan de voorwaarden voor financiering te voldoen. 
En, het geld komt natuurlijk niet altijd terug. In de media duiken geregeld voorbeelden op van investeringen die niet goed zijn gegaan. $U$ herinnert zich misschien het publieke geld dat is gestoken in de lingerie van Marlies Dekkers en in de hippe elektrische bussen van het Helmondse APTS. Nou, dat geld is foetsie.

Maar er zijn ook revolverende fondsen die het heel erg goed doen. Neem het Nationaal Restauratiefonds dat in 1985 werd opgericht. ledere euro aan publiek geld was eind 2014 al voor de derde keer uitgegeven.

Uit de onderzoeken blijkt verder dat het risico op marktverstoring altijd op de loer ligt. Sommige overheden eisen van een revolverend fonds dat innovaties financiert een realistische revolverendheid van $45 \%$. Andere innovatiefondsen moeten ervoor zorgen dat $100 \%$ van het publieke geld terugkomt. $U$ begrijpt dat om dat rendement te kunnen behalen, investeren in risicovolle innovatieve projecten op zijn zachtst gezegd onhandig is. Het gevaar bestaat dat publiek geld in projecten wordt gestoken die uitstekend door private investeerders kunnen worden gefinancierd.

Het is verder lastig te achterhalen of het via revolverende fondsen geïnvesteerde publieke geld iets oplevert voor de belastingbetaler. Sommige fondsen lijken meer te zijn gericht op het behalen van een zo hoog mogelijk rendement, dan op het ondersteunen van relevante maatschappelijke projecten. In dat geval rijst de vraag of met deze fondsen wel uitvoering wordt gegeven aan een publieke taak, zoals de wet vereist.

Ook blijkt uit de praktijk dat niet altijd is geregeld wat er met het publieke geld gebeurt wanneer het fonds wordt opgeheven. Wanneer geen exit-strategie voorhanden is, bestaat het risico dat het publieke geld in het fonds blijft zitten en nooit meer bij de overheid terugkeert.

Ten slotte blijkt uit verschillende rapporten dat men in de praktijk worstelt met de informatievoorziening naar de betrokken democratisch gelegitimeerde organen, zoals de Tweede Kamer en provinciale staten. Hoewel in veel gevallen wel informatie wordt verstrekt, blijkt deze lastig te doorgronden. Controleren of het publiek geld uitgezet door middel van een fonds goed terechtkomt, is gewoon razend ingewikkeld.

Samengevat: in de praktijk is men vol enthousiasme met revolverende fondsen aan de slag gegaan. Dat loopt soms goed, maar er zijn ook forse problemen en vraagstukken. Of dit opweegt tegen de voordelen? Daar is vervolgonderzoek voor nodig.

\section{Wat zijn de meest dringende juridische problemen met deze revolverende fondsen?}

Het kernprobleem met revolverende fondsen is dat miljarden aan publiek geld worden weggezet, terwijl we niet weten of het werkt en niet is gewaarborgd dat publiekrechtelijke of daarmee vergelijkbare normen in acht worden genomen.

Dat laatste probleem zou er helemaal niet hoeven zijn. 
We hebben in Nederland immers gewoon regels voor het verstrekken van publiek geld door de overheid voor het stimuleren van wenselijke activiteiten, namelijk de subsidietitel van de Algemene wet bestuursrecht. Deze subsidietitel bevat het subsidiebegrip, namelijk:

- een aanspraak op financiële middelen

- door een bestuursorgaan verstrekt,

- met het oog op bepaalde activiteiten van de aanvrager,

- anders dan als betaling voor aan het bestuursorgaan geleverde goederen en diensten.

ledere financiële verstrekking van de overheid die voldoet aan deze omschrijving, valt onder de regels van de subsidietitel van de Awb en is daarmee omkleed met publiekrechtelijke waarborgen. Zowel uit de toelichting op de subsidietitel als de jurisprudentie blijkt dat ook leningen en garanties onder het subsidiebegrip vallen. De veel gehoorde stelling dat door revolverende fondsen verstrekte garanties en leningen geen subsidies zijn omdat zij marktconform worden verstrekt, is niet overtuigend. Fondsen pretenderen immers slechts garanties en leningen te verstrekken waar de markt het laat afweten. Dit betekent dat per definitie geen sprake is van marktconforme verstrekkingen.

Ook een participatie valt naar mijn mening vaak onder het subsidiebegrip. In 1998 was de gedachte van de wetgever dat het daarbij niet gaat om een aanspraak op financiële middelen met het oog op bepaalde activiteiten. Aandelenkapitaal zou juridisch niet aan een bepaalde besteding kunnen worden gebonden; het dient per definitie alle huidige en toekomstige activiteiten van de vennootschap. Deze gedachte is achterhaald.

Voor revolverende fondsen geldt namelijk dat de overheid in de meeste gevallen enig aandeelhouder is en dat in hun investeringsinstructies klip en klaar wordt omschreven in welke categorieën ondernemingen mag worden geïnvesteerd. Daarom wordt wel degelijk geïnvesteerd "met het oog op bepaalde activiteiten van de aanvrager".

Kortom: participaties, garanties en leningen die door revolverende fondsen worden verstrekt kwalificeren als een aanspraak op financiële middelen in de zin van de subsidietitel van de Awb.

Deze aanspraak moet echter wel worden verstrekt door een bestuursorgaan. En daar gaat het wat betreft de revolverende fondsen in veel gevallen mis - of goed, het is maar net hoe je het bekijkt.

De meeste revolverende fondsen worden als gezegd privaatrechtelijk vormgegeven. De bestuursrechtjuristen onder ons weten dat ook privaatrechtelijke entiteiten kunnen kwalificeren als een Awb-bestuursorgaan, namelijk als zij met openbaar gezag zijn bekleed. Voor het financieren door revolverende fondsen wordt echter bijna nooit een wettelijke grondslag gecreëerd. In dat geval is een revolverend fonds in principe niet met openbaar gezag bekleed en dus geen $b$ bestuursorgaan.

Op grond van de jurisprudentie is het echter mogelijk om ook zonder wettelijke grondslag als bbestuursorgaan te kwalificeren. Voorwaarde is dat aan twee cumulatieve vereisten is voldaan. Deze vereisten heeft de Afdeling bestuursrechtspraak van de Raad van State in september 2014 opnieuw geformuleerd. Het gaat in de eerste plaats om het financiële vereiste. Dit vereiste houdt in toegespitst op revolverende fondsen - dat zo'n fonds in beginsel voor twee derden of meer moet 
zijn gevuld met publiek geld van a-bestuursorganen, zoals Gedeputeerde Staten of de minister. In de tweede plaats geldt het inhoudelijke vereiste. Dit houdt in dat a-bestuursorganen in beslissende mate bepalen waar het publieke geld naar toe gaat.

Veel revolverende fondsen worden zodanig opgezet dat juist niet aan deze twee voorwaarden is voldaan.

Een voorbeeld biedt het fonds UNIIQ. Een fonds dat erop is gericht om unieke innovaties sneller naar de markt te brengen. De 22 miljoen die dit fonds heeft te besteden, bestaat voor 100\% uit publiek geld. Toch is niet aan het financiële vereiste voldaan. Acht miljoen euro aan publiek geld is namelijk niet rechtstreeks afkomstig van a-bestuursorganen, maar van stichtingen en BV's van de universiteiten van Delft, Rotterdam en Leiden en de gemeente Den Haag. Dit is $36 \%$ van de totale financiële middelen van UNIIQ. De $64 \%$ publieke gelden afkomstig van het college van B\&W van de gemeente Rotterdam en de gemeente Leiden zijn 'toevalligerwijs' dus net niet genoeg om de financieringen door UNIIQ als subsidie te kleuren.

Het tweede voorbeeld dat ik vandaag wil noemen ziet op een fonds dat niet aan het inhoudelijk criterium voldoet: het Fonds Nieuwe Doen. Dit fonds verstrekt leningen in de zorg, leefbaarheid en energie in de provincie Groningen. Het investeringsreglement waarin wordt bepaald waaraan het publieke geld wordt uitgegeven, is bewust vastgesteld door de directie van dit fonds. Zo wordt voorkomen dat de provincie Groningen een beslissende invloed heeft op de inhoudelijke selectiecriteria. Het Fonds Nieuwe Doen kwalificeert dus niet als buitenwettelijk b-bestuursorgaan.

Dit illustreert naar ik hoop voor $u$ dat een revolverend fonds met een beetje slim rekenen en regelen buiten de Awb en het subsidiebegrip kan worden gehouden. Zo kunnen overheden wegblijven van publiekrechtelijke normering en rechtsbescherming. Overheden geven dat ook ruiterlijk toe. Zij doen daarbij aan kansberekening: de kans dat een fonds ooit voor de bestuursrechter komt wordt als nihil ingeschat.

Betrokken overheden gaan er dus vanuit dat de financiële verstrekkingen door privaatrechtelijk vormgegeven revolverende fondsen niet door het publiekrecht worden genormeerd.

En dat vinden zij wel zo prettig.

Deze visie wordt bevestigd in de wetgeving die is voorzien voor de op te richten NV Invest-NL. Voor dit revolverend fonds van 2,5 miljard wordt - als alles doorgaat - een bevoegdheid gecreëerd in een wet in formele zin om te investeren en financieren. Toch lijkt het niet de bedoeling dat Invest-NL wordt genormeerd door het publiekrecht. Volgens een niet onderbouwde terloopse opmerking in de memorie van toelichting kwalificeert Invest-NL namelijk niet als bestuursorgaan. Eerstejaars rechtenstudenten leren echter al dat wanneer een privaatrechtelijke rechtspersoon een wettelijke bevoegdheid krijgt om eenzijdig rechten en plichten in het leven te roepen, wel degelijk sprake is van een bestuursorgaan. Deze manier van wetgeven illustreert dat men graag wegblijft van publiekrechtelijke normering van een revolverend fonds dat met publiek geld is gevuld. Lees hierover trouwens meer in het NJB van vandaag.

Revolverende fondsen worden in veel gevallen dus niet door het publiekrecht genormeerd. Is dit erg? 
Een eerste gevolg is dat de financiële verstrekkingen die revolverende fondsen doen, beperkt democratisch zijn gelegitimeerd. Weliswaar zijn democratisch gelegitimeerde organen, zoals Provinciale Staten en de Tweede Kamer, betrokken bij de oprichting van een revolverend fonds en de bijbehorende investeringsinstructie, maar zij hebben weinig tot geen invloed op de individuele financiële verstrekkingen die vervolgens door het revolverend fonds worden gedaan. Hoewel uiteraard om informatie kan worden verzocht, gebeurt dit in de praktijk weinig. Als het mis gaat, weet men vaak niet eens dat het om publiek geld gaat.

De informatie die vanuit de bestuurders zelf wordt verstrekt, is door gebruik van geconsolideerde overzichten een zoekplaatje.

Ook is een transparante en daarmee eerlijke verdeling van publieke gelden door een revolverend fonds niet gegarandeerd. Uit jurisprudentie van de Afdeling bestuursrechtspraak van de Raad van State volgt dat bestuursorganen schaarse publieke rechten, waaronder publiek geld, op een transparante wijze moeten verdelen om gelijke kansen te bieden aan potentiële gegadigden. Deze jurisprudentie geldt echter alleen voor bestuursorganen en dat zijn fondsen niet, zo bespraken wij hiervoor. Ook in de praktijk blijkt lastig te achterhalen aan welke criteria moet worden voldaan, om voor financiering door een revolverend fonds in aanmerking te komen.

Op gelikte maar gemakkelijk aan te passen websites zijn uitsluitend globale omschrijvingen terug te vinden. Voor het overige wordt geadviseerd om contact op te nemen met de fondsmanager. Zeer klantvriendelijk, maar niet transparant en geen waarborg voor de gelijke behandeling van aanvragers. Bovendien hebben fondsbeheerders de vrijheid om op basis van hun professionele kennis een leningaanvraag te weigeren, wanneer zij geen vertrouwen hebben in het voorgestelde project of de betrokken ondernemer. Ook als aan alle vastgestelde criteria om voor financiering in aanmerking te komen, is voldaan. Logisch misschien vanuit investeerdersperspectief, maar minder goed te rijmen met overheidshandelen, waarbij transparantie en gelijke behandeling het uitgangspunt horen te zijn.

Revolverende fondsen zijn verder niet gebonden aan de algemene beginselen van behoorlijk bestuur, zoals het beginsel van onpartijdigheid, zorgvuldige voorbereiding en het motiveringsbeginsel. Deze beginselen gelden immers alleen voor bestuursorganen.

Ook de Wet openbaarheid van bestuur (de Wob) is niet vanzelfsprekend van toepassing op revolverende fondsen. De Wob geldt immers alleen voor bestuursorganen en voor een onder verantwoordelijkheid van een bestuursorgaan werkzame instelling, dienst of bedrijf. Van dit laatste is niet snel sprake: het hebben van bevoegdheden op grond van aandeelhouderschap en afhankelijkheid van publiek geld is onvoldoende. Dit betekent dat het lastig is om als burger, journalist of wetenschapper aan informatie te komen over investeringsbeslissingen die revolverende fondsen nemen.

Verder geldt ook de Wet normering topinkomens (de Wnt) doorgaans niet voor werknemers van revolverende fondsen. Deze wet heeft als doel om de beloning van topfunctionarissen in de publieke en semipublieke sector aan banden te leggen. De Wnt is, behoudens een paar uitzonderingen, echter niet van toepassing op besloten en naamloze vennootschappen: de rechtsvorm van de meeste revolverende fondsen. Het risico hiervan is dat fondsmanagers riant worden beloond. 
Controle door een onafhankelijke rekenkamer is evenmin gegarandeerd. Ook niet als een revolverend fonds voor $100 \%$ met publiek geld is gevuld.

Een voorbeeld biedt het participatiefonds van de Zuid-Hollandse regionale ontwikkelingsmaatschappij Innovation Quarter. De Algemene Rekenkamer heeft geen bevoegdheid om een onderzoek ter plaatse te doen, omdat de Staat 'slechts' 36\% van de aandelen houdt. Omdat de provincie Zuid-Holland eveneens 'maar' 36\% van de aandelen houdt, is ook de Randstedelijke Rekenkamer niet bevoegd tot het doen van onderzoek. Dit betekent dat een fonds dat geheel wordt gefinancierd met publiek geld, vrij gemakkelijk aan effectief toezicht door een onafhankelijke rekenkamer kan ontkomen.

En last but not least: de rechtsbescherming. Wanneer een revolverend fonds niet kwalificeert als een bestuursorgaan, staat geen rechtsbescherming open bij de bestuursrechter. Een teleurgestelde aanvrager van financiering is dus veroordeeld tot het indienen van een klacht bij het fonds zelf of tot de theoretische gang naar de dure en lijdelijke civiele rechter. Want: wat moet je als onderneming stellen bij de civiele rechter? Dat een fonds onrechtmatig heeft gehandeld door geen lening te verstrekken? Opvallend is dat afgewezen aanvragers nauwelijks schijnen te protesteren, terwijl het overgrote deel van de aanvragen wordt afgewezen. Aanvragers doorlopen een lang traject en de afwijzing van de aanvraag is minder formeel vormgegeven; soms gebeurt dat zelfs telefonisch. Ik vergelijk het maar met een hypotheekaanvraag: wanneer de Rabobank u geen hypotheek wil verstrekken, dan haalt u het ook niet in uw hoofd om naar de rechter te stappen. Hetzelfde psychologische effect ontstaat bij de als bank vermomde overheid. Fundamenteel verschil is echter wel dat de door revolverende fondsen verstrekte financiering met publiek geld wordt bekostigd.

Kortom: revolverende fondsen zetten voor miljarden euro's aan publiek geld weg, terwijl tot nu toe door gebruik van het privaatrecht democratisch gelegitimeerde organen, rekenkamers, algemene beginselen van behoorlijk bestuur, de Wob, de Wnt en de bestuursrechtelijke rechtsbescherming vrij geruisloos en zeer effectief buiten de deur worden gehouden.

Waarom, vraagt u zich ongetwijfeld af.

Het antwoord op deze vraag hangt samen met het al genoemde negatieve imago van de subsidie. Potentiële particuliere investeerders zouden het bestuursrecht als een afbreukrisico zien en dat zou de mogelijkheden tot inzet van revolverende middelen verminderen. Bedrijven zouden bovendien eenvoudigweg geen subsidies meer willen hebben. Daarnaast is het bestuurs- en subsidierecht veel te ingewikkeld, zeker als het subsidiegeld wordt verdeeld door middel van complexe tenderprocedures.

Verder gaat het bij investeren om de match tussen investeerder en ondernemer die moet worden beklonken met een overeenkomst, champagne en een foto. Daarbij past geen eenzijdige beschikking van een bestuursorgaan.

Een transparante verdeling van publiek geld en openbaarheid staan verder haaks op de werkwijze van de professionele investeerder. Wanneer geen vertrouwen bestaat in de onderneming wil de fondsmanager de ruimte houden om niet te investeren. Ook wanneer aan alle voorwaarden is voldaan. Gegarandeerde geheimhouding van documenten die zien op aangevraagde en gedane investeringen is bovendien wel zo safe. 
Bestuursrechtelijke rechtsbescherming ten slotte staat garant voor ellenlange procedures die veel te veel geld kosten.

\section{Welke oplossingen zijn daarvoor denkbaar?}

Resumerend: wanneer de overheid voor het subsidie-instrument kiest, dan gelden allerlei publiekrechtelijke waarborgen zoals democratische legitimatie, transparante verdeling, algemene beginselen van behoorlijk bestuur, onafhankelijke controle en bestuursrechtelijke rechtsbescherming.

Wanneer de overheid ervoor kiest te financieren door middel van een revolverend fonds, dan verdwijnen deze waarborgen geruisloos van het toneel. Dat is opmerkelijk: het gaat immers om hetzelfde publieke geld en vaak om projecten die ook worden gesubsidieerd. En publiek geld verplicht. Het is onwenselijk dat overheden met het inzetten van hetzelfde instrument in een andere verpakking aan fundamentele publieke waarborgen kunnen ontkomen.

Ik hoor sommigen van u denken: wat heb je aan fundamentele publieke waarborgen wanneer deze resulteren in hopeloos ouderwets overheidshandelen? Bovendien worden deze publieke waarborgen op een andere wijze meegenomen, namelijk door het kiezen van een passende governancestructuur. Laat ik hier het volgende over zeggen: wanneer het bestuurs- c.q. subsidierecht als hopeloos ouderwets wordt ervaren, dan ligt daar een uitdaging om dit te moderniseren. Als de overheid in staat is om nieuwe creatieve stimuleringsinstrumenten te bedenken, dan moet het toch ook mogelijk zijn om daarin publiekrechtelijke waarborgen in te passen? Tijdens het congres van vandaag is gebleken dat hiervoor genoeg creatieve ideeën bestaan.

Verder is het inderdaad zo dat bij het opzetten van revolverende fondsen aandacht is voor 'de governance'. Zo hebben sommige provincies ervoor gekozen dat een fonds publiekrechtelijke normen, zoals de Wnt en de Wob, in acht moet nemen, ook al zijn deze normen strikt genomen niet van toepassing. Ook wordt aan rekenkamers de mogelijkheid geboden om onderzoek te doen en er bestaat in veel gevallen een klachtenregeling.

Transparantie, openbaarheid, efficiënte besteding van publieke middelen en rechtsbescherming zijn echter afhankelijk van particuliere inzichten, toeval, de gemaakte afspraken en bovendien niet afdwingbaar bij een onafhankelijke bestuursrechter. Het is dus twijfelachtig of flexibele governance daadwerkelijk een volwaardig alternatief biedt voor de normale publiekrechtelijke normering.

Hoe kunnen we ervoor zorgen dat publiekrechtelijke waarborgen bij het verstrekken van financiering uit revolverende fondsen niet in een governancemist verdwijnen?

Het meest eenvoudig is om de bevoegdheid tot het verstrekken van financiering door revolverende fondsen wettelijk vast te leggen en vervolgens de subsidietitel van de Awb toe te passen. We hebben gezien dat leningen, garanties en met een beetje goede wil ook participaties als subsidies kwalificeren. Als men het geen subsidie wil laten heten, verklaart men de subsidietitel gewoon van overeenkomstige toepassing, net zoals bij de onderwijsbekostiging is gebeurd. 
Dat dit geen utopie is, wordt bevestigd door voorbeelden van revolverende fondsen waarbij de betrokken overheid wel bewust kiest voor normering door het publiekrecht. In dat geval worden leningen en garanties in de vorm van subsidies verstrekt. Een voorbeeld is het innovatiekrediet dat wordt verstrekt door de minister van Economische Zaken op grond van de Regeling nationale EZsubsidies. In de schriftelijke versie van deze oratie die dit najaar verschijnt, noem ik nog meer voorbeelden. Er is geen bewijs voor dat dit minder effectief is dan een privaatrechtelijk revolverend fonds dat leningen en garanties in de vorm van een privaatrechtelijke overeenkomst verstrekt.

Het voordeel van het gebruik van de subsidietitel van de Awb is niet alleen dat voormelde publiekrechtelijke waarborgen zijn gegarandeerd, maar ook dat er een duidelijk wettelijk kader is. Dit heeft onder meer tot gevolg dat overheden bij het opzetten van revolverende fondsen niet steeds het wiel opnieuw hoeven uit te vinden, met alle transactiekosten van dien.

Het is echter de vraag of het realistisch is dat de subsidietitel van de Awb zal worden toegepast op verstrekkingen door revolverende fondsen. Hoewel nauwelijks met onderzoeksresultaten of juridische argumenten onderbouwd, wordt de subsidie heden ten dage beschouwd als een ontoereikend instrument.

\section{Welke lessen zouden wij kunnen leren uit het EU-recht?}

Toepassing van de subsidietitel van de Awb is dus misschien wel verstandig, maar voorlopig weinig reëel. Is er dan misschien een derde weg? In dat verband heb ik onderzocht wat wij kunnen leren van de Unierechtelijke regels over revolverende fondsen. Ook in EU-verband wordt namelijk geëxperimenteerd met het wegzetten van EU-gelden door middel van participaties, leningen en garanties. Deze zogenoemde financieringsinstrumenten vormen een alternatief voor de eveneens met imagoproblemen kampende EU-subsidie.

Vorige maand nog presenteerde de Europese Commissie plannen voor een nieuw te creëren fonds InvestEU - gevuld met 15,2 miljard euro, dat binnen de EU voor 650 miljard aan publieke en private investeringen hoopt aan te trekken.

Ook de lidstaten worden bij de uitvoering van Europese financieringsinstrumenten betrokken. Met EU-geld afkomstig uit de Europese Structuur- en Investeringsfondsen zijn inmiddels vele revolverende fondsen opgezet. In de huidige programmaperiode 2014-2020 vindt dit EU-geld onder meer zijn weg via het al genoemde revolverend fonds UNIIQ en binnenkort waarschijnlijk via Invest$\mathrm{NL}$.

Ook in de EU geldt als voordeel dat hetzelfde geld meerdere keren kan worden ingezet, rendement kan worden behaald en private investeerders kunnen worden aangetrokken. Voor eindontvangers van financieringsinstrumenten geldt bovendien dat bij hen niet door nationale autoriteiten mag worden gecontroleerd. Dit betekent een enorme vermindering van administratieve lasten ten opzichte van ontvangers van traditionele EU-subsidies.

Maar ook in de EU is het niet al goud wat blinkt, zo blijkt uit verschillende onderzoeken van de Europese Rekenkamer. Het lukte vaak niet om op fondsniveau daadwerkelijk particuliere investeringen aan te trekken. Verder werden financieringsinstrumenten nogal eens misbruikt als 
parkeerplaats voor EU-gelden om te voorkomen dat deze gelden aan de Europese Commissie moesten worden terugbetaald. De Europese Rekenkamer concludeerde verder dat het Unierechtelijk wettelijk kader aan alle kanten rammelde en - niet onbelangrijk - dat de beheerskosten van financieringsinstrumenten relatief hoog waren.

Deze kritiek heeft ertoe geleid dat in 2014 een wettelijk kader voor de uitvoering van Unierechtelijke financieringsinstrumenten tot stand is gekomen.

Hoewel niet in het allermooiste proza, valt op dat in dit wettelijk kader allerlei waarborgen zijn terug te vinden die, zowel op Unierechtelijk niveau als in de Nederlandse rechtsorde, een evenknie hebben in het subsidierecht.

Interessant daarbij is dat het Unierecht niet dwingend voorschrijft of het toekennen van financieringsinstrumenten publiekrechtelijk dan wel privaatrechtelijk moet worden vormgegeven. Dit is ook logisch: de gewoonten op dit vlak verschillen per lidstaat. Daarom is het verstandiger om de lidstaten zelf te laten bepalen of het financieringsinstrument privaatrechtelijk dan wel publiekrechtelijk wordt ingericht. Welke keuze ook wordt gemaakt: dit heeft geen consequenties voor de toepasselijke normen.

Met andere woorden: de Unierechtelijke waarborgen gelden ook wanneer de lidstaten ervoor kiezen financieringsinstrumenten langs de privaatrechtelijke weg uit te voeren.

Welke waarborgen gelden er dan precies?

Belangrijk is dat in het Financieel Reglement - in deze verordening staan de Europese begrotingsregels - als hoofdregel is neergelegd dat voor het gebruik van een financieringsinstrument een Unierechtelijke wettelijke grondslag dient te bestaan. Daarmee worden zij democratisch gelegitimeerd.

Het EU-recht schept verder een aantal waarborgen om te voorkomen dat publiek geld wordt verspild. Zo dient voordat financieringsinstrumenten mogen worden ingezet, een evaluatie te worden uitgevoerd. Daarmee moet worden aangetoond dat onvoldoende financiering op de markt beschikbaar is. Zo is gewaarborgd dat publiek geld alleen daar wordt ingezet waar dat echt nodig is en de concurrentie niet onnodig wordt verstoord. Ook is geregeld wat er moet gebeuren met leningen die aan een revolverend fonds worden terugbetaald. Hiermee wordt voorkomen dat publiek geld uit de publieke context verdwijnt.

Belangrijk is verder dat is vastgelegd dat fondsbeheerders eindontvangers van participaties, leningen en garanties moeten selecteren in overeenstemming met het transparantiebeginsel. Helaas moet hier wel bij worden gezegd dat nog vrij onduidelijk is wat dit precies betekent binnen het Unierechtelijke subsidie- en financieringsrecht. Ook andere rechtsbeginselen, zoals evenredigheid, non-discriminatie en gelijke behandeling zijn expliciet van toepassing verklaard.

Verder is op Unie-niveau een aantal financieringsinstrumenten gestandaardiseerd, zodat het voor nationale autoriteiten eenvoudiger wordt om deze instrumenten juridisch vorm te geven. Hiermee 
wordt beoogd de hoge uitvoeringskosten van een revolverend fonds omlaag te krijgen.

Ook onafhankelijk toezicht op de besteding door revolverende fondsen van EU-geld uit de Europese Structuur- en Investeringsfondsen is gewaarborgd. De Europese Rekenkamer kan niet alleen controleren bij de fondsmanagers, maar ook bij de eindontvangers van door hen verstrekte financiering.

Ten slotte geldt dat de lidstaten moeten zorgen voor een doeltreffende klachtenregeling. Onduidelijk is echter aan welke vereisten deze klachtenregelingen moeten voldoen. Evenmin is helder hoe deze klachtenregeling zich verhoudt tot het beginsel van effectieve rechtsbescherming op grond waarvan burgers en ondernemingen toegang tot de rechter moeten hebben wanneer lidstaten het EU-recht uitvoeren.

Hoewel de precieze reikwijdte en betekenis van al deze op EU-niveau vastgelegde waarborgen dus nog niet is uitgekristalliseerd, is wel duidelijk dat zij op grond van deze nieuwe wetgeving altijd van toepassing zijn, ongeacht of het revolverend fonds publiekrechtelijk dan wel privaatrechtelijk is vormgegeven.

\section{Conclusie}

In deze oratie heb ik u meegenomen naar de wondere wereld van het revolverend fonds. Miljarden euro's aan publiek geld worden door privaatrechtelijke entiteiten met privaatrechtelijke overeenkomsten weggezet, zonder dat 'normale' publiekrechtelijke waarborgen van toepassing zijn.

De blik op Europa leert ons dat gebruik van het privaatrecht geen argument hoeft te zijn voor het achterwege laten van deze waarborgen. De met EU-geld gevulde revolverende fondsen zijn onderworpen aan bepaalde waarborgen, ongeacht of de uitvoering in de lidstaten via het privaatrecht dan wel het publiekrecht plaatsvindt. Dit vind ik een aantrekkelijke gedachte.

Daarom pleit ik ervoor om ook voor Nederlandse revolverende fondsen een wettelijk kader te creëren, waarin de eis van een wettelijke grondslag en regels voor het financieren door een revolverend fonds worden neergelegd. Dit wettelijk kader past uitstekend in hoofdstuk 4 van de Algemene wet bestuursrecht; achter de subsidietitel. Een wettelijk kader betekent dat revolverende fondsen democratisch zijn gelegitimeerd, waardoor een adequate informatievoorziening richting vertegenwoordigende organen beter gewaarborgd is. Ook toepassing van de Wob en Wnt, regels voor een transparante verdeling en toepasselijkheid van de algemene beginselen van behoorlijk bestuur zijn in dat geval gegarandeerd. Wat de controle door een onafhankelijke rekenkamer betreft, zou moeten worden geregeld dat bij deelneming door meerdere overheden tenminste één onafhankelijke rekenkamer bevoegd is om onderzoek te doen naar de doeltreffendheid en doelmatigheid van het revolverend fonds. Standaardisering door middel van een wettelijk kader brengt bovendien de uitvoeringskosten omlaag. Overheden hoeven niet steeds zelf het wiel uit te vinden. Dan kunnen kosten aan duurbetaalde advocaten en adviseurs ook achterwege blijven. Bovendien kan met een wettelijk kader worden voorkomen dat een revolverend fonds minder doordacht wordt ingezet. 
De consequentie van een wettelijk kader is uiteraard dat revolverende fondsen - ook als zij zijn vormgegeven als een privaatrechtelijke rechtspersoon - kwalificeren als bestuursorgaan. Een wettelijk kader dat losstaat van de subsidietitel, biedt echter wel de mogelijkheid om slimme oplossingen te bedenken voor eventuele tekortkomingen van de subsidietitel van de Awb. Er zou bovendien kunnen worden nagedacht of bestuursrechtelijke rechtsbescherming efficiënter kan worden vormgegeven. Net als bij de terugvordering van staatssteun, zou kunnen worden gekozen voor beroep bij één bestuursrechter, namelijk het College van Beroep voor het bedrijfsleven.

Realistisch revolveren vereist toepassing van publiekrechtelijke waarborgen, waaronder toegang tot een betaalbare bestuursrechter. Een als bank vermomde overheid is misschien professioneler dan de doorsnee ambtenaar, maar nu eenmaal niet onfeilbaar.

Mevrouw de Rector Magnificus, geachte decaan, beste collega's, familie en vrienden,

Het is tijd om af te ronden met de gebruikelijke dankwoorden.

Om te beginnen bedank ik eenieder die aan mijn benoeming heeft bijgedragen.

Speciale vermelding daarbij verdienen vanzelfsprekend het College van Bestuur dat het formele benoemingsbesluit heeft genomen, het faculteitsbestuur en de externe en interne leden van de benoemingscommissie. Veel dank voor het in mij gestelde vertrouwen.

Beste collega's van de faculteit. Dankzij jullie was ik snel ingewerkt en kon ik aan de slag! Een speciaal woord van dank aan Saskia Klosse: ik hoop dat wij nog veel met elkaar zullen samenwerken. Ook mag een woord van dank aan de leden van de capgroep Publiekrecht en de sectie bestuursrecht niet ontbreken.

Beste oud-collega's uit Leiden. Ik vind het heel bijzonder dat jullie hier aanwezig zijn! Ik heb warme herinneringen aan jullie allemaal en ga daarom geen namen noemen :-D - ook niet die van jullie, Christien de Kruif en Jerfi Uzman. Een uitzondering maak ik voor Wim Voermans, Ymre Schuurmans en Michiel Tjepkema. Veel dank voor alle wijze raad die ik van jullie als DB-leden mocht ontvangen. Dan de oud-collega's van de Raad van State, waar mijn bestuursrechtelijke roots liggen. Dankzij de Raad plaats ik het hulpwerkwoord nog altijd voor het voltooid deelwoord. Een speciaal woord van dank aan Jaap Polak, Maria Vlasblom, Bart Jan van Ettekoven, Hanna Sevenster, Richte Dallinga en Olaf van Loon. Ik heb niet alleen inhoudelijk veel van jullie geleerd, maar ook mogen ervaren dat juristen vaak goede musici zijn!

Dan mijn promovendi: Clara van Dam, Louise Verboeket, Ellen Hardy, Esmée Driessen en sinds kort ook Maximillian Völlmer. Ik vind het een eervolle taak om jullie te coachen in jullie onderzoek. Ik hoop nog veel latte macchiatos met jullie te drinken.

Ook een woord van dank aan Tom Barkhuysen. Van jou heb ik geleerd dat ook in de wetenschap een geolied team onmisbaar is. Ik zal nooit vergeten dat je mij vroeg om in de eerste maanden van mijn aanstelling in Leiden vooral veel ongezouten feedback te geven op alles wat ik bizar en belachelijk vond. $U$ begrijpt dat ik hier veelvuldig gebruik van heb gemaakt ;-). 
Beste Rolf Ortlep: bedankt voor de collegiale samenwerking en ik hoop dat wij die samenwerking vanuit het zuiden nog lang zullen voortzetten.

Uiteraard mag mijn promotor Willemien den Ouden niet in mijn dankwoord ontbreken. Ik vind het bijzonder hoe jij jonge wetenschappers stimuleert en tot bloei laat komen! Dankzij jou en copromotor Paul Adriaanse, ben ik nu geen advocaat, maar hoogleraar. Ik leer nog steeds van jullie en hoop nog veel met jullie te mogen samenwerken.

Er zijn niet veel wetenschappers die zich verdiepen in het subsidierecht. Ik noemde Paul en Willemien al, maar Rianne Jacobs hoort ook in dat rijtje thuis. Na deze oratie gaan we samen met Willemien eindelijk de mastermonografie Subsidierecht afronden.

Dames en heren studenten. De afgelopen twee jaar heb ik in Maastricht met veel plezier onderwijsgroepen begeleid, hoorcolleges gegeven en scripties begeleid. Met schema's en plaatjes probeer ik het bestuursrecht en de europeanisering ervan levendig te presenteren in de hoop jullie klaar te stomen voor een mooie carrière!

Ik zie vandaag ook veel lieve familieleden en vrienden in de zaal: in een woord geweldig!

Verder ben ik erg dankbaar voor zulke fantastische ouders. Jullie hebben mij altijd gestimuleerd om gekregen talenten te benutten. Bovendien vinden de kinderen bij jullie een tweede thuis! Veel dank daarvoor.

Lieve Hilco, zonder jou werkte ik niet in Maastricht en was er vandaag ook geen feestje. Ik voel mij gezegend dat wij samen met Anne-Sophie, Marie-Hélène en Eva-Julie van het leven mogen genieten! Ik heb gezegd. 